\title{
Salinity on artificial reproduction of silver catfish (Rhamdia quelen)
}

\author{
Salinidade na reprodução artificial do jundiá (Rhamdia quelen)
}

\author{
Gabriel Bernardes Martins ${ }^{I^{*}}$ Sérgio Renato Noguez Piedras ${ }^{\mathrm{II}}$ Juvêncio Luís Osório Fernandes \\ Pouey $^{\text {II Denise Calisto Bongalhardo }}{ }^{\text {II III }}$ Ricardo Berteaux Robaldo ${ }^{\mathrm{I}}$, III
}

\begin{abstract}
Attempting to improve reproduction performance and ichthyo prophylaxis, this study evaluated the effects of maintaining silver catfish (Rhamdia quelen) broodstock in different saline concentrations (0, 2, 4, 6 and 8\%o) on gametes quality and reproductive viability. The results showed that sperm percent motility did not change between 0 and $4 \%$, but it was reduced at $6 \%$, and sperm became immotile at $8 \%$ salinity. Sperm motility time was increased (almost five fold) at $6 \%$. Salinities up to $4 \%$ prevented fertilization and hatching, proving their deleterious effects on oocytes and embryos. Therefore, media up to 4\%o salinity may be an alternative for icthyo prophylaxis, although fertilization and incubation must be done in freshwater medium.
\end{abstract}

Key words: semen, motility, eggs, fertilization, salt.

RESUMO

Com o intuito de otimizar o desempenho reprodutivo do jundiá Rhamdia quelen em cativeiro e evitar a ictioftiríase na larvicultura, o objetivo deste estudo foi avaliar os efeitos da manutenção de reprodutores em diferentes concentrações salinas $(0,2,4,6$ e 8\%o) sobre a qualidade dos gametas e viabilidade da reprodução nestes meios. Os resultados demonstraram que o percentual de espermatozoides móveis permaneceu inalterado nas concentrações salinas entre 0 e 4\%, reduziu em $6 \%$ e não houve motilidade a 8\%, e que o tempo médio de motilidade aumentou aproximadamente 5 vezes em 6\%. Entretanto, a fertilização e eclosão foram inviáveis a partir de 4\%o, demonstrando ação deletéria da salinidade sobre os ovócitos e também dos embriões. Assim, salinidade de até 4\%o pode ser empregada como método profilático ao ictio na manutenção de reprodutores de jundiá, embora a fertilização artificial e incubação tenham que ser realizadas em meio de água-doce.

Palavras-chave: sêmen, motilidade, ovos, fertilização, sal, ictio.

\section{INTRODUCTION}

Silver catfish (Rhamdia quelen, Quoy \& Gaimard, 1824), distributed from the south of Mexico to the center of Argentina, is a siluriform species that stands low winter temperatures and presents fast grow in the summer (BRAUN et al., 2006). To adjust reproductive performance, studies evaluating temperature and time of oocytes storage (SANCHEZ et al., 2011), and embryo incubation in different $\mathrm{Ca}^{+2}$ and $\mathrm{Mg}^{+2}$ concentrations (SILVA et al., 2003) have been made.

Reproduction control is a key matter on aquaculture and one limiting factor on reproductive success is gametes quality (BOBE \& LABBÉ, 2009). Teleost masculine gamete is immotile inside the seminal duct, acquiring motility when released in the media. Its activity is related to the ability to fecundate the oocyte; therefore, the knowledge of factors involved on sperm activation could improve fertilization (COSSON et al., 2008).

Some medium conditions are associated to sperm motility, such as $\mathrm{pH}$, osmolality, temperature,

\footnotetext{
'Laboratório de Piscicultura Estuarina e Marinha, Programa de Pós-graduação em Aquicultura, Universidade Federal do Rio Grande (FURG), Campus Cidade, Rua Alfredo Huch, 475, 96203-900, Rio Grande, RS, Brasil. Email: martins.aqua@gmail.com. *Corresponding author.

ILaboratório de Ictiologia, Departamento de Zootecnia, Programa de Pós-graduação em Zootecnia, Faculdade de Agronomia Eliseu Maciel (FAEM), Universidade Federal de Pelotas (UFPel), Pelotas, RS, Brasil.

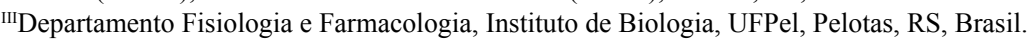


ionic concentrations $\left(\mathrm{Na}^{+}, \mathrm{K}^{+} \mathrm{e} \mathrm{Ca}{ }^{+2}\right)$ and dilution rate (ALAVI, 2005; 2006). In freshwater teleost, sperm motility is induced mainly by hyposmotic pressure and by dilution of $\mathrm{K}^{+}$seminal plasma concentration (ALAVI, 2006).

Salinity is known to directly affect egg fertilization, embryogenesis, normal egg and larvae survival and development, yolk reabsorption, and larval growth (BOEUF \& PAYAN, 2001). Studies demonstrated, for African catfish Heterobranchus longifilisi (FASHINA-BOMBATA \& BUSARI, 2003) and Nile tilapia Oreochromis niloticus (FRIDMAN et al., 2012), that low salt concentrations have positive effect on egg hatching.

One of the difficulties for massive catfish fingerlings development is the elevated concentration of the ciliated protozoan Ichthyophtirius multifilis, known as the white spot disease agent (BALDISSEROTTO \& NETO, 2005), responsible for the mortality of high quantities of fingerlings and juvenile in a few days (BOIJINK \& BRANDÃO, 2001). MIRON et al. (2003) and ANDRADE et al. (2006) proved the efficiency of $\mathrm{NaCl}\left(4 \mathrm{~g} \mathrm{~L}^{-1}\right)$ baths on the I. multifilis infestation of juveniles catfish.

Therefore, the objective of this study was to evaluate the effect of maintaining catfish broodstock in different concentrations of marine salt on the gamete quality and on artificial reproduction of Rhamdia quelen, in order to improve reproductive performance and to avoid the establishment of ichthyos starting from broodstock maintenance.

\section{MATERIAL AND METHODS}

In the sperm quality trial, 25 adult males, one year old, produced in the Ichthyology Laboratory from the Federal University of Pelotas - UFPel, were used. Fish were distributed in 180L boxes with water recirculation system, biological filter, constant aeration, natural photoperiod, and environmental temperature, under weekly renovation rate of $80 \%$ of total volume. Salinities tested were 0, 2, 4, 6 and $8 \%$ (marine salt without iodine). Acclimation to the experimental units occurred for 15 days after osmotic shock. Fish were daily fed (10\% of biomass) with a commercial diet (Supra Aqualine, $42 \%$ crude protein). Dissolved oxygen concentration (YSI 55, USA), temperature, and $\mathrm{pH}$ (Hanna HI221) were daily evaluated, while total ammonia (Nessler reagent) was weekly evaluated.

For semen collection, three individuals from each treatment were randomly selected, measured (total length), and weighted. Genital pore region was dried; semen was extruded by abdominal massage and collected with disposable syringe until blood appearance. Total semen volume was standardized in relationship to male weight $[=$ volume collected $(\mathrm{mL}) /$ male weight $(\mathrm{g})]$.

After collection, $5 \mu \mathrm{L}$ of semen was transferred to a slide and activated with $50 \mu \mathrm{L}$ of the respective treatment media. Immediately, the slide was covered with a coverslip for motility time analyses (chronometer, 1s) on optic microscope (400x magnification). Motility time was recorded till at least $25 \%$ of the cells presented horizontal displacement. Motility percent was determined by subjective estimation, using an arbitrary scale with $25 \%$ intervals. Motility degree was classified according to the scale established by HOGAN \& NICHOLSON (1987): 0 - inactive without movement, 1 - vibration without displacement, and 2 - fast displacement.

To demonstrate the relationship between spermatocrit and centrifugation time (centrifuge, $13,000 \mathrm{rpm}$ ), three males were selected (six capillary tubes for each), and semen was spun from five to $30 \mathrm{~min}$, with five min intervals.

For fertilization assays, breeders were maintained for acclimation in 0,4 , and $6 \%$ salinities (established according to male assay results) for 15 days, before being paired for induction in the same salinities. Six females $(1133 \pm 208 \mathrm{~g}$ and $45 \pm 3 \mathrm{~cm})$ and males $(590 \pm 85$ and $38 \pm 2 \mathrm{~cm})$ catfish pairs were induced with carp pituitary extract, $3 \mathrm{mg} \mathrm{kg}^{-1}$ for females, and $1.5 \mathrm{mg} \mathrm{kg}^{-1}$ for males. Couples were maintained in hapas $\left(20^{\circ} \mathrm{C}, \mathrm{pH} 7.8 \pm 0.2\right.$, natural photoperiod) under fasting.

From the eggs produced, lots with 400 units were destined to the same salinities $(0,4$, and $6 \%$ ) in tray incubators $(90 \%$ medium renovation twice a day), in the same condition as their respective broodstock. Fertility and hatch rates and larvae malformation percent were followed, as well as external and internal egg diameter (with and without the perivitelline gelatinous layer, respectively).

Means of total semen volume, motility time, spermatocrit, fertilization rate, and internal and external egg diameter were submitted to oneway analyses of variance (ANOVA), followed by Tukey test. Means of percent and degree of motility were compared with Kruskal-Wallis non-parametric ANOVA, followed by multiple comparison mean ranks test. Hatch rate and larvae malformation percent were compared by Mann-Whitney "U" test. All tests considered $95 \%$ of significance level, and results are expressed as mean \pm standard deviation. 


\section{RESULTS AND DISCUSSION}

Water quality parameters during the trial had the following values: $8.1 \pm 0.7 \mathrm{mg} \mathrm{L}^{-1}$ dissolved oxygen, non-detectable total ammonia $\left(<0.01 \mathrm{mg} \mathrm{L}^{-1}\right)$, $22 \pm 1.7^{\circ} \mathrm{C}$ temperature, and $8.57 \pm 0.07 \mathrm{pH}$. At the end of the trial, fish did not show significant difference in mean weight $(136 \pm 56 \mathrm{~g})$ and mean total length $(25.2 \pm 3.4 \mathrm{~cm})$

During salinity acclimation, there was no mortality. CAMARGO et al. (2006) proved that catfishes are capable of osmoregulate in salinities up to $8 \%$ o for 30 days, with $100 \%$ survival and without erythrocyte parameters alteration.

In the pre-trial for determination of semen centrifugation time, it was observed a stabilization of values after $15 \mathrm{~min}$ of processing (Figure 1); therefore, this was the time used. Besides a significant spermatocrit difference between 4 and $8 \%$, the variation did not appear to respond to media salinity (Table 1).

Semen volume (Table 1), when correlated with individual weight, did not show significant difference among treatments. BORGES et al. (2005) showed similar values of spermatocrit and semen volume for catfish.

Sperm motility time in the present study (Figure 2), in control as well as in hyposmotic media, was typical from freshwater teleosts, with approximately 30-40s of activity in freshwater and up to 200 s in brackishwater. SANCHES et al. (2010) reported sperm motility for $\boldsymbol{R}$. quelen and also observed reduced motility time; $15 \mathrm{~s}$ after activation, $60 \%$ of the cells were motile in freshwater.

The $8 \%$ treatment was not able to start sperm motility, however it was verified that sperm became motile when further exposed to the $2 \%$ media; activation occurred and mean motility time was $75 \mathrm{~s}$. Inactivity observed in the highest salinity could be due to the solution osmolality, which is close to the species seminal plasma $\left(275 \mathrm{mOsm} \mathrm{kg}^{-1}\right)$ (BORGES et al., 2005). In this way, silver catfish presents sperm activation only in hyposmotic solutions in relation to seminal plasma, similar to most freshwater teleosts. The same was demonstrated for catfish Clarias batrachus (MORITA et al., 2006) and northern pike Esox lucius (ALAVI et al., 2009), where sperm motility

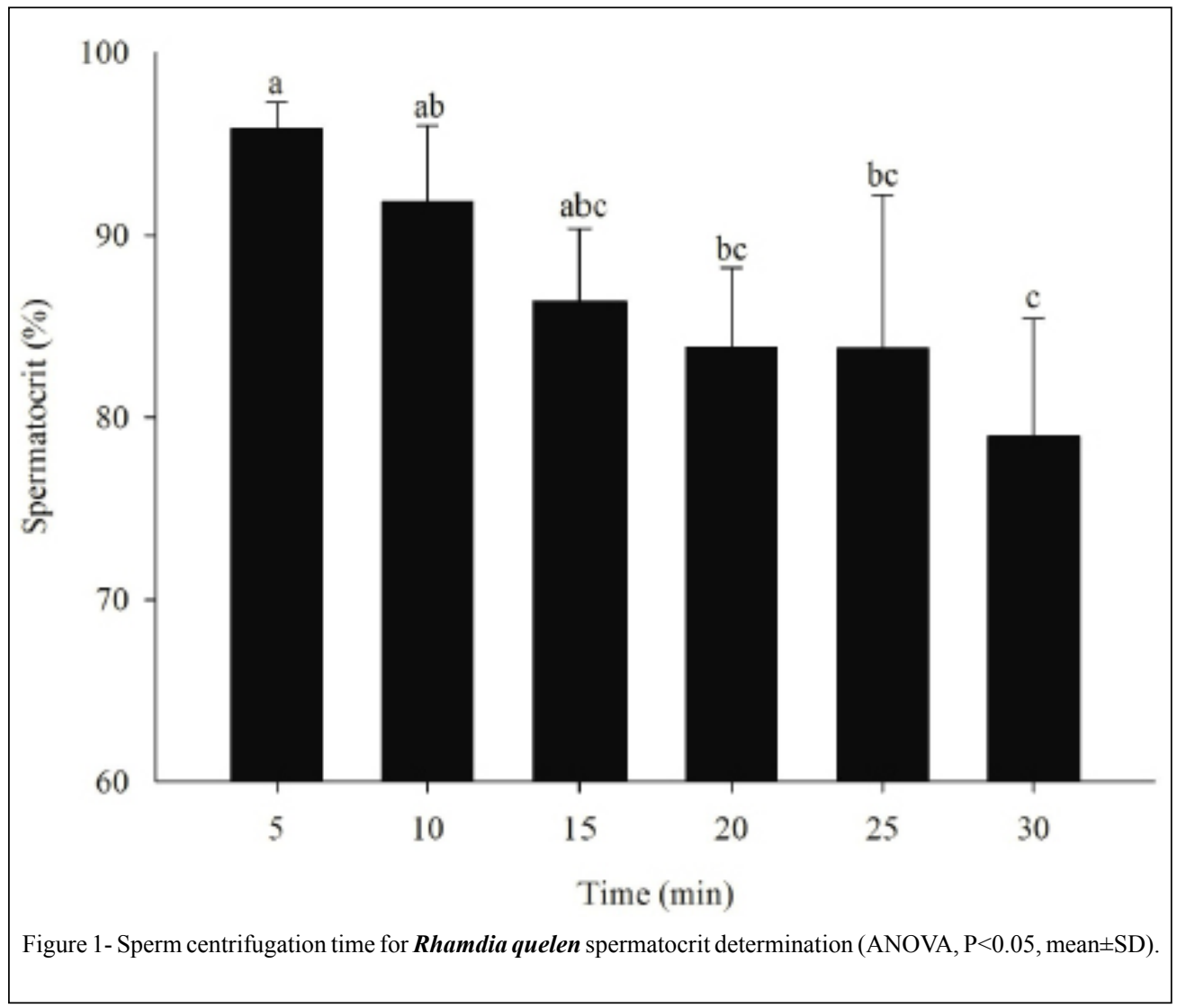

Ciência Rural, v.45, n.3, mar, 2015. 
Table 1 - Effect of salinity on spermatocrit, semen total volume, motile cells percent, time and degree of sperm motility of $\boldsymbol{R} \boldsymbol{h a m}$ dia quelen.

\begin{tabular}{|c|c|c|c|c|c|}
\hline Salinity (\%o) & Spermatocrit (\%) & Semen volume $\left(\mathrm{mLkg}^{-1}\right)$ & Motile cells percent ( $\%)$ & Motility time (s) & Motility degree \\
\hline 0 & $88.9 \pm 4.3^{\mathrm{ab}}$ & $4.0 \pm 2.2^{\mathrm{a}}$ & $75-100$ & $38 \pm 10^{\mathrm{ab}}$ & 2 \\
\hline 2 & $89.5 \pm 3.1^{\mathrm{ab}}$ & $1.7 \pm 0.4^{\mathrm{a}}$ & $75-100$ & $206 \pm 118^{c}$ & 2 \\
\hline 4 & $91.4 \pm 3.6^{b}$ & $3.3 \pm 1.5^{\mathrm{a}}$ & $75-100$ & $200 \pm 52^{\mathrm{bc}}$ & 2 \\
\hline 6 & $88.5 \pm 1.8^{\mathrm{ab}}$ & $2.9 \pm 2.1^{\mathrm{a}}$ & $25-50$ & $226 \pm 79^{c}$ & 2 \\
\hline 8 & $87.0 \pm 2.8^{\mathrm{a}}$ & $3.0 \pm 2.9^{\mathrm{a}}$ & 0 & $0 \pm 0^{\mathrm{a}}$ & 0 \\
\hline
\end{tabular}

Distinct letters demonstrate significant difference among means (ANOVA;Tukey; $\mathrm{P}=0.05$ ).

occurred only in solutions hyposmotic in relation to seminal plasma.

Previous studies with silver catfish demonstrated that $\mathrm{pH}$ does not influence activation capacity and sperm motility time (FERREIRA et al., 2001). Therefore, increases in osmolality, in values below the isosmotic point of seminal plasma, could be the main responsible factor for sperm activation. However, the saline media that presented the highest sperm displacement time are not suitable for catfish fertilization and incubation (Table 2).

Exposing eggs and embryos to salinity $(>4 \%$ ) significantly impaired reproductive success.
External and internal egg diameter (Table 2) demonstrated a relationship proportionally inverse to media salinity (respectively: $\mathrm{Y}=9.77-0.69 . \mathrm{X} ; \mathrm{r}^{2}=0.93$; $\mathrm{P}=0.0000$, and $\mathrm{Y}=4.90-0.17 \mathrm{X} ; \mathrm{r}^{2}=0.59 ; \mathrm{P}=0.0000$ ). This deleterious effect probably occurred due to osmotic imbalance, since the reduced egg diameter reflects a dehydration process of the gelatinous layer, which limits the external diameter, as well as of the internal diameter, revealing effects on the developing embryo. Those effects could be associated with the reduced or null hatchability of normal larvae.

Larvae mean total length in $0 \%$ salinity was $14.15 \pm 0.44 \mathrm{~mm}$ and vitelline sac diameter was

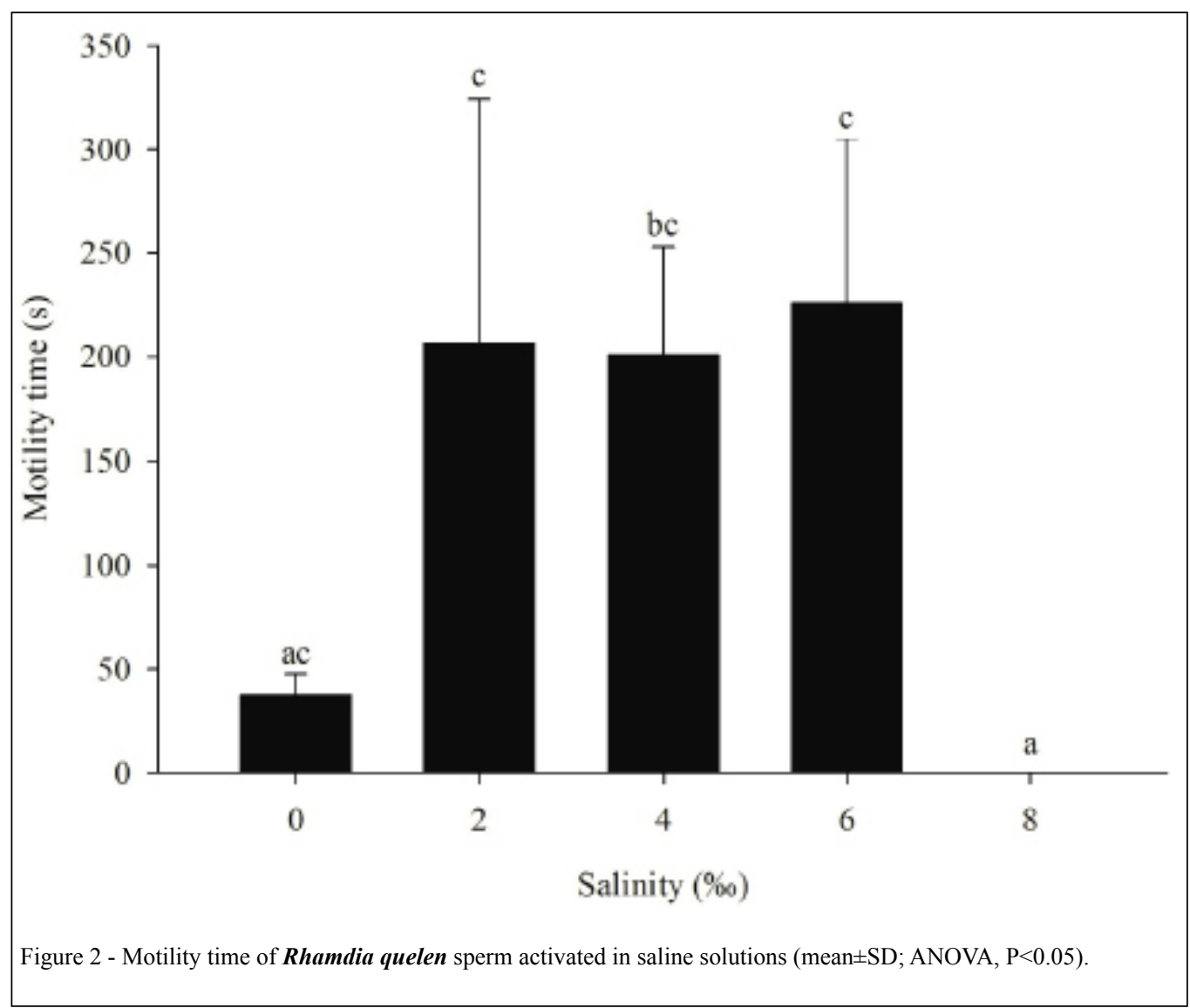

Ciência Rural, v.45, n.3, mar, 2015. 
Table 2 - Effect of salinity on Rhamdia quelen reproduction. Fertilization (FR), hatch (HR), and malformed larvae (MFR) rates, external (ED) and internal (ID) egg diameter.

\begin{tabular}{llllll}
\hline Salinity (\%) & FR (\%) & HR $(\%)$ & MFR (\%) & ED (mm) & ID (mm) \\
\hline 0 & $93.8 \pm 1.2^{\mathrm{a}}$ & $83.2 \pm 2.6^{\mathrm{a}}$ & $3.8 \pm 0.4^{\mathrm{a}}$ & $10.0 \pm 0.07^{\mathrm{a}}$ & $5.01 \pm 0.05^{\mathrm{a}}$ \\
4 & $85.6 \pm 4.8^{\mathrm{a}}$ & $2.2 \pm 0.2^{\mathrm{b}}$ & $94.5 \pm 5.5^{\mathrm{b}}$ & $6.34 \pm 0.05^{\mathrm{b}}$ & $3.98 \pm 0.05^{\mathrm{b}}$ \\
6 & $0.0 \pm 0.0^{\mathrm{b}}$ & -- & -- & $6.04 \pm 0.08^{\mathrm{c}}$ & $4.05 \pm 0.03^{\mathrm{b}}$ \\
\hline
\end{tabular}

Distinct letters demonstrate significant difference among means. FR, ED and ID (ANOVA; Tukey; $\mathrm{P}<0.5$; $\mathrm{n}=6$ ). HR and MFR (Mann Whitney; $\mathrm{P}<0.05 ; \mathrm{n}=6$ ).

$3.72 \pm 0.11 \mathrm{~mm}$ (Table 2). Malformed larvae were not measured due to a lack of morphological pattern.

In general, freshwater teleost embryos tolerate low salinity. BART et al. (2013) demonstrated that incubation of Nile tilapia embryos at $4 \%$ presents higher hatch rate than at freshwater or at $12 \%$. However, according to the results of the present study, it is not possible to perform fertilization and incubation of silver catfish in low salinity media.

\section{CONCLUSION}

The utilization of marine salt without iodine, in concentrations between 2 and 4\%, could be used as prophylactic agent for ichthyos in silver catfish Rhamdia quelen broodstock, with improvements in sperm quality; although fertilization and incubation must be done in freshwater medium.

\section{ETHICS COMITTE AND BIOSECURITY}

This project was approved by the Animal Experimentation Ethical Committee from the Federal University of Pelotas (CEEA-UFPel, \# 5.06.03.022).

\section{ACKNOWLEDGMENTS}

This study was supported by the National Council for Scientific and Technological Development (CNPq, Brasília, DF, Brazil) and R. Robaldo is a research fellow from CNPq (Proc. \# 307478/2012-2).

\section{REFERENCES}

ALAVI, S.M.H.; COSSON, J. Sperm motility in fishes: I. Effects of $\mathrm{pH}$ and temperature. Cell Biology International, v.29, p.101-10, 2005. Available from: <http://dx.doi.org/10.1016/j. cellbi.2004.11.021>. Accessed: Feb. 04, 2013. doi:10.1016/j. cellbi.2004.11.021.

ALAVI, S.M.H; COSSON, J. Sperm motility in fishes. (II) Effects of ions and osmolality: a review. Cell Biology International, v.30, p.1-14, 2006. Available from: <http://www.ncbi.nlm.nih. gov/pubmed/16278089>. Accessed: Feb. 04, 2013. doi:10.1016/j. cellbi.2005.06.004.
ALAVI, S.M.H. et al. Effect of osmolality on sperm morphology, motility and flagellar wave parameters in Nothern pike (Esox lucius L.). Theriogenology, v.72, n.1, p.32-43, 2009. Available from: $<$ http://www.ncbi.nlm.nih.gov/pubmed/19269024>. Accessed: Feb. 04, 2013. doi: 10.1016/j.theriogenology.2009.01.015.

ANDRADE, L.S. et al. Survival and behavior of silver catfish, Rhamdia quelen, submitted to antibiotics and sodium cloride treatments. Ciência Rural, v.36, n.3, p.1004-1007, 2006. Available from: $\quad<$ http://www.scielo.br/scielo.php?script=sci arttext\&pid=S0103-84782006000300047\&lng=en\&nrm=iso $>$. Accessed: Feb. 04, 2013. doi:10.1590/S0103-84782006000300047.

BALDISSEROTTO, B.; NETO, J.R. Jundiá (Rhamdia sp.). In: BALDISSEROTTO, B.; GOMES, L.C. Espécies nativas para a piscicultura no Brasil. Santa Maria: UFSM, 2005. p.303-325.

BART, A.N. et al. Effects of incubation water hardness and salinity on egg hatch and fry survival of Nile tilapia Oreochromis niloticus (Linnaeus). Aquaculture Research, v.44, p.1085-1092, 2013. Available from: $<$ http://onlinelibrary.wiley.com/doi/10.1111/ j.1365-2109.2012.03113.x/full>. Accesssed: Apr. 18, 2013. doi:10.1111/j.1365-2109.2012.03113.x.

BOBE, J.; LABBÉ, C. Egg and sperm quality in fish. General and Comparative Endocrinology, v.165, p.535-548, 2009. Available from: $<$ http://www.sciencedirect.com/science/article/pii/ S0016648009000756>. Accessed: Mar. 12, 2013. doi: 10.1016/j. ygcen.2009.02.011.

BOEUF, G.; PAYAN, P. How should salinity influence fish growth? Comparative Biochemistry and Physiology Part C, v.130, p.411-423, 2001. Available from: <http://www.sciencedirect.com/ science/article/pii/S153204560100268X>. Accessed: Mar. 12, 2013. doi: 10.1016/S1532-0456(01)00268-X.

BOIJINK, C.L.; BRANDÃO, D.A. Alterações histológicas e comportamentais provocadas pela inoculação de suspensão bacteriana (Aeromonas hydrophila) em juvenis de jundiá (Rhamdia quelen). Ciência Rural, v.31, n.4, p.687-690, 2001. Available from: <http://www.scielo.br/pdf/cr/v31n4/a21v31n4. pdf>. Accessed: Mar. 12, 2013.

BORGES, A. et al. Biochemical composition of seminal plasma and annual variations in semen characteristics of jundiá Rhamdia quelen (Quoy and Gaimard, Pimelodidae). Fish Physiology and Biochemistry, v.31, p.45-53, 2005. Available from: $<$ http://link. springer.com/article/10.1007\%2Fs10695-005-4742-8>. Accessed: Mar. 28, 2013. doi: 10.1007/s10695-005-4742-8.

BRAUN, N. et al. Survival, growth and biochemical parameters of silver catfish, Rhamdia quelen (Quoy \& Gaimard, 1824), juveniles 
exposed to different dissolvid oxygen levels. Aquaculture Research, v.37, p.1524-1531, 2006. Available from: <http:// onlinelibrary.wiley.com/doi/10.1111/j.1365-2109.2006.01589.x/ abstract>. Accessed: Mar. 28, 2013. doi: 10.1111/j.13652109.2006.01589.x.

CAMARGO, S.G.O. et al. Efeito da salinidade nos parâmetros hematológicos do jundiá (Rhamdia quelen - Quoy \& Gaimard, 1824). Revista Brasileira de Agrociência, v.12, n.4, p.453-460, 2006. Available from: <http://www.ufpel.edu.br/faem/agrociencia/ v12n4/artigo12.htm>. Accessed: Mar. 12, 2013.

COSSON, J. et al. Studying sperm motility in marine fish: an overview on the state of the art. Journal of Applied Ichthyology, v.24, p.460-86, 2008. Available from: <http://onlinelibrary.wiley. com/doi/10.1111/j.1439-0426.2008.01151.x/abstract>. Accessed: Mar. 12, 2013. doi: 10.1111/j.1439-0426.2008.01151.x.

FASHINA-BOMBATA, H.A.; BUSARI, A.N. Influence of salinity on the developmental stages of African catfish Heterobranchus longifilis (Valenciennes, 1840). quaculture, v.224, p.213-222, 2003. Available from: <http://www.sciencedirect.com/science/ article/pii/S0044848603002734> . Accessed: Mar. 12, 2013. doi: 10.1016/S0044-8486(03)00273-4.

FERREIRA, A.A. et al. Avaliação qualitativa e quantitativa do sêmen de jundiá, Rhamdia quelen. Boletim do Instituto de Pesca, v.27, n.1, p.57-60, 2001. Available from: <ftp://ftp.sp.gov. br/ftppesca/arq_27_art_09.pdf>. Accessed: Mar. 12, 2013.

FRIDMAN, S; BRON, J; RANA, K. Influence of salinity on embryogenesis, survival, growth and oxygen consumption in embryos and yolk-sac larvae of the Nile tilapia. Aquaculture, v.334-337, p.182-190, 2012. Available from: <http://www. sciencedirect.com/science/article/pii/S0044848611010167>. Accessed: Mar 12, 2013. doi:10.1016/j.aquaculture.2011.12.034.

HOGAN,A.E.; NICHOLSON, J.C. Sperm motility of Sooty Grunter, Hephaestus fuliginosus (Macleay), and jungle perch, Kuhlia rupestris (Lacépede), in different salinities. Australian Journal of Marine and Freshwater Research, v.38, p.523-528, 1987. Available from: <http://www.publish.csiro.au/paper/MF9870523. htm>. Accessed: Mar. 12, 2013. doi:10.1071/MF9870523.

MIRON, D.S. et al. Efficacy of different salt $(\mathrm{NaCl})$ concentrations in the treatment of Ichthyophthirius multifilis infected silver catfish, Rhamdia quelen, fingerlings. Journal of Applied Aquaculture, v.14, p.155-161, 2003. Available from: $<$ http://www.tandfonline.com/doi/abs/10.1300/J028v14n01_12\#. UfArFtK7K4Q >. Accessed: Mar. 12, 2013. doi:10.1300/ J028v14n01_12.

MORITA, M. et al. Changes in sperm motility in response to osmolality $/ \mathrm{Ca}^{2+}$ in three Indonesian fresh water teleosts: Goby (Oxyeleotris marmorata), Java carp (Puntius javanicus), and catfish (Clarias batrachus). Comparative Biochemistry and Physiology Part A, v.143, p.361-367, 2006. Available from: $<$ http:// www.sciencedirect.com/science/article/pii/S1095643305004253>. Accessed: Mar. 12, 2013. doi:10.1016/j.cbpa.2005.12.020.

SANCHES, E.A. et al. Sperm motility of Rhamdia quelen studied using computer-assisted analysis by open-source software. Aquaculture Research, v.42, p.153-156, 2010. Available from: <http://onlinelibrary.wiley.com/doi/10.1111/ j.1365-2109.2010.02598.x/abstract>. Accessed: Mar. 28, 2013. doi:10.1111/j.1365-2109.2010.02598.x.

SANCHES, E.A. et al. Time and temperature on the storage of oocytes from jundiá catfish, Rhamdia quelen. Aquaculture, v.319, p.452-458, 2011. Available from: <http://dx.doi. org/10.1016/j.aquaculture.2011.07.036>. Accessed: Mar. 12, 2013. doi: 10.1016/j.aquaculture.2011.07.036.

SILVA, L.V.F. et al. Incubation of silver catfish, Rhamdia quelen (Pimelodidae), eggs at different calcium and magnesium concentrations. Aquaculture, v.228, p.279-287, 2003. Available from: <http:// www.sciencedirect.com/science/article/pii/S0044848603002655\#>. Accessed: Mar. 10, 2013. doi:10.1016/S0044-8486(03)00265-5. 